\title{
ISLAMIC EDUCATION DEVELOPMENT BASED ON UNITY OF SCIENCES PARADIGM
}

\author{
Mahfud Junaedi and Mirza Mahbu6 Wijaya \\ Universitas Islam Negeri Walisongo Semarang, Indonesia \\ E-mail: mahfudjunaedi@walisongo.ac.id
}

\begin{abstract}
The focus of this research lies in the philosophical analysis of Islamic education based on the Unity of Sciences paradigm. So far, no researcher has studied this issue specifically and comprehensively. This study uses a philosophical and phenomenological approach of library research. The finding shows that the development of managed Islamic education has both human and divine potential. Unity of Sciences has become the basis for creating a balanced Islamic education paradigm with humanization and spiritualization strategies. Therefore, development of Islamic education based on Unity of Sciences can produce modern scientists who are religious and not anti-local culture. Thus, this paradigm encourages scientists to dialogue and reciprocally lead someone closer and closer to God, the Most True (al-Haqq). This paradigm is implemented into the curriculum at State Islamic University (UIN) Walisongo Semarang.
\end{abstract}

Fokus penelitian ini terletak pada analisis filosofis pendidikan Islam yang berbasis pada paradigma Kesatuan Ilmu. Sejauh ini, belum ada peneliti yang mengkaji isu tersebut secara spesifik dan komprehensif. Penelitian ini menggunakan pendekatan filosofis dan fenomenologis dengan jenis studi pustaka. Hasil riset ini menunjukkan bahwa pengembangan pendidikan Islam yang dikelola memiliki potensi manusia dan ilahi. Kesatuan Ilmu menjadi dasar untuk menciptakan paradigma pendidikan Islam yang seimbang dengan strategi humanisasi dan spiritualisasi. Dengan demikian, 
pengembangan pendidikan Islam berbasis Unity of Sciences dapat menghasilkan ilmuwan modern yang religius dan tidak anti dengan budaya lokal. Maka, paradigma ini mendorong para ilmuwan untuk berdialog dan timbal balik mengantarkan seseorang yang lebih akrab dan lebih dekat kepada Tuhan, Yang Maha Benar (al-Haqq). Paradigma ini diimplementasikan ke dalam kurikulum yang ada di Universitas Islam Negeri Walisongo Semarang.

Keywords: Islamic education; paradigm; scientific development; Unity of Sciences

Received: October 05, 2021; Accepted: December 27, 2021

\section{Introduction}

Several verses in the Quran discuss the closeness between science and religion (Syarifah and Fahimah 2020, 290). Allah is the source of knowledge that has paved the way so that humans can easily recognize the existence and all of His perfect dispositions through two verses, namely the Kawniyah verses and the Qur'aniyah. The Kawniyah is existence proof and all the essence of His omnipotence that unfolds in the universe, and the Qur'aniyah is verses contained in the Quran and sunnah. Several academics have discussed this. One of them was tried by an academic from the University of Damascus named Muhammad Ijazul Haq. He found 750 verses out of 6,236 verses of the Quran that talk about science (Yaqin 2016, 38). There are strong indications in these verses that Muslims are primarily intellectuals to be creative and always think creatively in studying natural phenomena and making scientific activities an integral practice for Muslims (Nasr 2001, $3)$.

In the modern era, empirical and rational scientific discoveries and methods have brought tremendous progress in science and technology. Since then, human life has entered a new era called the modern era (Latif 2018, 276). Advances in science and the sophistication of modern technology bring the problems faced by humans (society) in the modern era increasingly complex and complicated (Fathorrahman 2020, 42). It is a paradigm in the lives of Western people who have made science-like knowledge that is always true and has an authentic character that only deals with phenomena. The criteria for measuring a single truth are only measured by empirical and ratio. Such a view arises because Western 
perspective science is not built on the foundation of revelation (Rozi 2012, 242). It is built with human creations armed with a secular life philosophy speculation that focuses on humans as creatures. The implication is the erosion of ethical values that govern science.

This is what Syed Naquib al-Attas criticizes. This view is basically out of the concept of Islamic epistemology. Such a Western worldview can harm humans, such as confusion and skepticism. The West has brought a culture of skepticism and speculation to a scientific level in methodology. Western civilization views that doubt as a sufficient good and specific epistemological means for pursuing the truth. It has brought the West to the pinnacle of world civilization. However, the negative impact is to create chaos (chaos) or damage to the three kingdoms of nature, namely animals, plants, and minerals (Al-Attas 1979, 79).

Ismail al-Faruqi has an idea, a mutualism relationship between reality and theological aspects, called the Islamization of Knowledge (Hussien, Mamat, and Abdallah 2018, 118). It is the same with Syed Muhammad alAttas. Although the concept of Islamization of knowledge offered by the two figures is not entirely the same (Sa'adi 2011, 153), the substance offered leads to the same benefits. The question is, how can the application of science as the basis of human progress not be separated from the spiritual aspect, which is based on the normative side of the Quran and sunnah? (Wijaya, Junaedi, and Sholihan 2021, 3-4) It is the same when understanding the text of revelation. Humans also need to use their minds. Otherwise, Muslims will be left behind by other nations. Due to the reality, currently, science plays a significant role in determining the progress level of humankind (Rifai et al. 2014, 6).

In its historical record, education can build civilization, so the existence of an Islamic education paradigm is a must. The Islamic world was once the mecca of science and technology and reached its peak during the Abbasid caliphate (Saqeb 2000, 48). At that time, all intellectual activities were based on religious values. Therefore, all activities' ultimate goal was to balance uphold religious disciplines and intellectual development in the educational curriculum (Razali and Awang 2014, 220).

From the various problems of Islamic education above, education practitioners have begun to reconstruct the paradigm of Islamic education so the expected final goals can be achieved (Alhamuddin 2016, 93). The world of education is strongly influenced by globalization. It is also felt in higher education which directly interacts with the international community. 
In particular, globalization urges the formation of a change in the position of large learning institutions. The position as a traditional educational institution cannot be maintained anymore and needs to be replaced as a knowledge-creating institution. Meanwhile, plans made at random (by accident) must be replaced with strategic planning (by design). From the point of view of challenges, the comparative approach must be replaced with a competitive approach (Aziz et al. 2016, 754).

To realize it all, of course, required a set of methods or systems in learning. The curriculum can make people become good citizens and determine a country's sense of identity (Jama et al. 2020, 67). The curriculum can be understood as part of all aspects of the teaching and learning process in writing and used as a guide to achieving the goals expected by an institution (Alhamuddin 2016, 5).

At first, the idea of transforming State Islamic Institute (IAIN) to State Islamic University (UIN) made IAIN Walisongo academics develop an appropriate paradigm. Therefore, a workshop on the development of UIN Walisongo was carried out in the future. It resulted in the Paradigm Development Blueprint (Blueprint Pengembangan Akademik IAIN/UIN Walisongo Untuk 25 Tahun (2013-2038) IsDB IAIN Walisongo 2013), but there are still some weaknesses in its implementation. One of them is the lack of references and writings about the unity of sciences paradigm. Several academics publish about this, for example, Muhyar Fanani, who developed a concept map of the symbol of the unity of science (Fanani 2015). Next, Solihan developed an epistemology of the unity of science in the field of da'wah (Sholihan, 2015). Thus, the author's position is to provide a map of the concepts of ontology, epistemology, and axiology in professional and applied sciences represented by Islamic education.

However, the concept of Islamic education in the framework of scientific integration at each of these UINs has editorial and elaboration diversity which is very contextual to the environment of each UIN. Thus, a paradigm or frame is needed to build a comprehensive Islamic education. Therefore, what exactly is meant by that paradigm?

This research is literature-based research that aims to find answers to the problems outlined previously. Using a philosophical and phenomenological approach, the concept of Islamic religious education based on Unity of Sciences is trying to be presented. The primary data source used by researchers is the BluePrint for the Development of UIN Walisongo 2013-2038. The secondary data are in books and scientific 
journal articles by UIN Walisongo academics related to scientific integration developed by the State Islamic University (UIN) Walisongo, such as the writings of Muhyar Fanani and Fatah Syukur. After obtaining the research data, the authors analyzed the data using content analysis.

\section{Islamic Education Paradigm}

Islamic education can be translated as tarbiyyah Islâmiyyah. It contains the concept of ta'lîm (instruction), ta'dîl (rear or sustain), and other subconcepts, such as hikmah (wisdom), 'adl (justice), amânah (trust), and the extreme is khalifah (caliph) and 'ibâdah (worship). The primary sources in Islamic education are the Quran and hadith. Islamic education connotes the whole approach to life and signifies full integration in human life (Tahir Abdurrahman Abubakar et al. 2016, 176).

Education is the most effective tool to continue, maintain, preserve, and as a strategy for preserving traditions from one generation to the next, from one century to another (Abdullah 2017). It is the first tangible system to guide man away from the darkness of ignorance and illiteracy towards intellectual progress. It creates lots of relevance and benefits not only for Muslims but also for all humankind. According to the Islamic view, education is part of the task of the human caliphate that must be carried out responsibly. Then accountability can only be demanded if there are rules and guidelines for implementation (Hasibuan 2016, 49). Therefore, Islam certainly provides outlines about the execution of education. Islam provides the basic concepts of education, and it is human responsibility to explain by applying these basic concepts in the practice of education.

Paradigm comes from the Greek (paradigm). While in English, paradigm is defined as a pattern model, or an example. In popular scientific dictionaries, the term paradigm is defined as, definition, example guideline, (Partanto and Barry 2001, 556) or can also be called the foundation of thinking that is the basis of science. A paradigm is synonymous with a worldview, a general way of looking at things, or a way of describing complexity. The notion of worldview is a belief, perspective, and everything that has been conceptualized in people's reasoning in social and moral change. The same perspective as the worldview is defined as the human view of the world of reality. In other words, a worldview can be understood as an integral basic belief system about the nature of the human self, reality, and the meaning of existence (Junaedi and Wijaya 2019, 312). 
From this historical fact, there is a basic assumption that Islamic education has a special experience overcoming the organic unity between science and religion. Because pre-modern sciences such as China, India, and Muslim civilization have basic comparisons with modern science, for example, in terms of purpose, methodology, sources of inspiration, and their philosophical assumptions about man, knowledge, and the reality of the universe (Nasiruddin 2013, 179).

Therefore, it is expected for a scholar of Islamic education to be able to explain the rules of science and religion in the form of methods of thinking and behavior (morals) in an integrated and evenly (holistic) in citizens so that in the future, a better citizen order is created (Nasiruddin, 2013, p. 179). Thus, Islamic education in the future can contribute to producing scientists, technologists and engineers, and other reliable groups.

\section{Unity of Sciences}

The unity developed by UIN Walisongo is a union between all branches of science by providing a basis for revelation as a setting or binding to unification. To clarify the description of the Unity of Sciences paradigm, see the following diagram:

\section{Figure 1}

Scientific Integration Metaphor

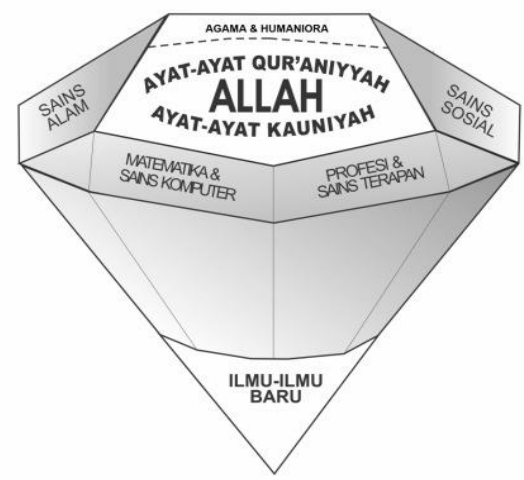

In figure 1 the middle circle is a revelation, while the outer circle is nature. Whereas, the other five roundabouts are religion and humanities, social sciences, natural sciences, mathematics and computing science, and professions and applied sciences. Figure 1 requires that the unity of all 
science must be derived from revelation both directly and indirectly. It is also in the realm of nature, all of which comes from God. It is in line with Wan Mohd Nor Wan Daud, "The existence of one god who is the source of all knowledge directly entails the unity and integrality of all epistemological sources and ends" (Daud 1989, 66).

At present, UIN Walisongo has built the integration of science developed with the foundation of a paradigm called Unity of Sciences (Wahdat al'Ulum). The paradigm was intended to deliver the lecturers getting to know and get closer to Allah as al-Alim (the omniscient). The following explains specifically about the Unity of Sciences paradigm (Wahdat al'Ulûm). Repositioning as an Islamic tertiary institution as a forum for integrating knowledge to be a systematic, well-structured construction by becoming a scientific paradigm. Basically, the vision of UIN Walisongo has been in line with Islamic teachings.

Wan Mohd Nor Wan David explained with the same substance, "the relationship between disciplines of knowledge and their integrality and compatibility with the Islamic weltanschaung is also evidence from the fact that many prophets of God where taught other forms of knowledge apart from divine revelations" (Daud 1989, 67). The paradigm that becomes the scientific foundation of UIN Walisongo, the Unity of Sciences (Wahdat al'Ulûm) can be defined as, "all knowledge is a unified and interconnected one that originates and empties to Allah with local adaptation". The Unity of Sciences paradigm as a project scientific integration also has an epistemological scope. As Wan Mohd Nor Wan Daud has said, the concept of knowledge in Islam is, "extends to both the religious sphere as well as the secular, because the Islamic weltanschaung does not admit the durable compartmentalization between these concerns in actual life" (Daud 1989, 66). The idea can break the notion that during this time UIN Walisongo taught the sciences which are usually considered inanimate objects or "celestial bodies" because they are considered inapplicable (Azizy 2001, 3).

Unity of sciences can be likened to a federal state like the United States of America. Here, any science is allowed to develop like a country in the US. However, all countries are united by certain things such as foreign policy and taxes. That is one scientific entity. Each branch of science is bound in one entity directly and indirectly and rooted in revelation and nature (Fanani 2015, 52). Therefore, the term Unity of Sciences (Wahdat al 'Ulûm) has a special meaning. This term has been agreed to become the 
paradigm adopted by this institution. This paradigm affirms that all sciences dialogue with each other and lead to one goal, which is to bring the teacher to get to know and get closer to Allah, the al-Haqq.

\section{Ontological Dimension of Islamic Education Paradigm}

Ontologically, Islamic education is part of the professional development science group (Wijaya 2019, 215). It means the study of the combination of two or more sciences to solve human problems factually. AlGhazâlî has a view on the science of the profession as a teacher. According to him, the teaching profession should be borne by a person who is a unity between knowledge and charity. Teachers are people who are knowledgeable, charitable, and teach.

Similarly, with other professions, such as judges and accountants, science and charity must be in line and inappropriate if they overlap. According to al-Ghazâlî, whoever is knowledgeable, charitable, and teaches then is a great person in the realm of high malakut. The Hujjat al-Islâm likens the teacher to the sun, which shines a light on the universe and shines on itself (al-Ghazali 1998, 77). Teachers also like fragrant musk oil and bring fragrance to the surrounding environment (Syukur and Junaedi 2017, 71).

In line with this, the paradigm of Unity of Sciences seeks to develop knowledge that can be useful, not just theories that are less relevant to the development of the times. In addition, teachers should stay away from the greedy nature of the world and the madness of honor. Teachers must train themselves not to eat much, not to talk much, not to sleep much, to increase prayers, alms, and fasting. Teachers must also make good morals as their character, such as honest, patient, grateful, trustworthy, generous, qana' $a h$, quiet, and calm. If the requirements are met, then the teacher's figure is a personal reflection of the Prophet who should be emulated, helpful to others but empty, or like a candle that illuminates the surrounding environment. Still, he melts burning, or also like a needle. In addition to these conditions, according to the author, it is essential to add another condition, namely religious requirements. Religious requirements are the primary and first requirements (Syukur and Junaedi 2017, 72).

Islamic education as a representation of the professional discipline is a complex process that includes an introduction, core, conclusion, or simply is a process of apperception towards evaluation. There are several ideas in the integration-interconnection framework, as follows: 
First, philosophical level integration. The philosophical integration level in science-social integration in PAI (Islamic religious education) learning aims to dialogue other disciplines concerning humanistic values. Case studies of Fiqh, for example, in addition to its fundamental meaning as a philosophy of building relationships between humans, nature, and God in Islamic teachings, in the teaching of Fiqh must be reorganized and developed together with other scientific disciplines such as philosophy, sociology, psychology, etc.

Second, the integration level of research methods and approaches. The methodology referred to, in this context, is a methodology designed and used in the development of related sciences such as PAI. In a broader sense, in the form of an approach. For example, in Islamic education (IPI), the methodology and approach used is students' practical experience during their studies by observing the activities of Islamic educational institutions. While the philosophy of Islamic education course applies a deductive thinking pattern, which departs from the truth that exists in Islam, then looks at the phenomena in society. Also, inductive thinking patterns mean that various educational cases are associated with the norms that exist in Islam.

Third, material level integration. The material level integrates universal truth values in general with Islamic studies in particular into social science. In case studies and teaching astronomy, teaching astronomy for the ithbât process to determine the beginning of fasting or holidays must also involve physics and astronomy. As the teaching of Fiqh Munakahat (marriage), it is also necessary to introduce national law and its contextualization with Islamic law. At this level, UIN Walisongo needs to make UIN Sunan Kalijaga with an integration-interconnection approach that already has books or lecture materials. The number of books and lecture materials based on Unity of Sciences needs to be developed to bring together various theories in Islamic studies with modern theories.

Fourth, strategy level integration. If the material level shows the materials provided will be delivered in the learning process, then the strategy level is the stage of implementing learning by applying various models and methods in learning. Learning with active learning models with derivatives of various methods, techniques, and learning tactics is necessary to be chosen and practiced by teachers during the learning process. If teachers face limitations and weaknesses in their implementation, team 
teaching can be formed with teachers across scientific fields to facilitate integrative learning. The more scientific disciplines integrated with a lesson, the more it will require several varied learning strategies and involve many teachers to teach the field of science being studied.

Fifth, evaluation level integration. After the entire PAI learning process is completed, the evaluation level is carried out to know how much success and failure, strengths and weaknesses, and which parts need remedial training. The level of evaluation cannot be ignored because the learning process cannot be known without evaluation. Educational evaluation is briefly interpreted as an assessment activity in the educational process. PAI learning, in the end, needs to be evaluated to measure the achievement of the objectives of the learning itself (Hidayat 2014, 285).

Scientific integration can and should be done in all universal learning. However, in professional and applied disciplines, PAI lecturers or teachers would be better off engaging with social science or, otherwise, social-science learning that integrates with Islamic scholarship. Therefore, the scientific dichotomy that tends to damage the balance of civilization can be avoided. Thus, every Unity of Sciences-based profession must be established on a religious attitude.

\section{Epistemological Dimension of Islamic Education Paradigm}

In the epistemological area, Islamic education cannot be separated from the role of science. According to Naquib al-Attas, the epistemology of contemporary Islamic scholarship can be analogous to the human self consisting of various faculties and senses, both physical and spiritual. In addition, humans also have a soul and mental potential (inner being), in the form of spirit, soul (nafs), heart (qalb), and reason. These potentials constitute a unity that cannot stand alone (Al-Attas 1979, 154).

Likewise, the structure of human knowledge consists of fard kifâyah sciences and fard 'ayn sciences. The science of fard kifâyah is related to the ability and power of the human senses. This science in al-Ghazâlî's classification is called the intellectual sciences (intellectual knowledge). The fard 'ayn sciences are related to the spirit, nafs, qalb, and 'aql, called religious knowledge. Both of these knowledge is based on the knowledge of God. Likewise, with the scientific structure in Islamic universities, which includes the entire structure of human science, both fard kifâyah sciences and fard 'ayn sciences (Al-Attas 1979, 79). 
As explained by Naquib al-Attas, it is clear that the object of knowledge is not existence, as is the basis of the epistemology of Western science, but the meaning of that existence. Meaning is the knowledge obtained not only because of the act of reason but also because of God's guidance, through the knowledge source of the heart (qalb). By assuming that knowledge can be obtained through external senses (empiricism) alone, it has reduced reality to merely a world experienced by the senses. So it will negate God and the spiritual realm from existing (being) (Al-Attas 1979, 19).

Muhammad Naquib al-Attas also explained the concept of ta'dîb. For al-Attas, ta'dîb recognition and recognition of reality, knowledge, and everything that exists consists of a hierarchy according to the categories and levels. Everyone has their place concerning their reality, capacity, physical, intellectual, and spiritual potential. Adab has a close relationship with wisdom (hikmah), justice ('adl), reality and truth (haq). In other words, adab implies knowing the concept of wisdom, the concept of justice, and the concept of truth. Therefore, adab plays a substantial role in human life, including the following:

First, adab towards oneself admits that it has two elements, namely reason, and animality. When a person's mind can control his animal nature, he has put it in the right place to do justice for himself. Otherwise, he has done injustice to himself (zulm al-nafs). Second, adab towards fellow human beings, namely understanding the context of human relations, means treating fellow humans fairly. Third, adab towards science is an intellectual discipline that recognizes the existence of a hierarchy of knowledge based on its criteria. Adab towards science will result in correct and correct ways of learning and applying various sciences. Fourth, adab towards nature means putting plants, rocks, and animals in their habitats and places where they should be. Some of the concepts of adab are a unity that must complement each other (Hasibuan 2016, 52). It is in accordance with the principles of collaboration and dialectics in the development blueprint. There must be an intense dialogue between the sciences rooted in revelation (revealed sciences), modern sciences, and local wisdom (Blueprint Pengembangan Akademik IAIN/UIN Walisongo Untuk 25 Tahun (2013-2038) IsDB IAIN Walisongo 2013, 15; Suharto 2015, 252).

Furthermore, the concept of ta'dîb as education for al-Attas already includes the process and education concept because education is not a 
process that will only produce specialists, but a process that produces good individuals and masters in various fields of science integrally and coherently. Thus there are no longer any doubts and doubts about accepting $t a^{\prime} d \hat{\imath} b$ as a concept of Islamic education (Hasibuan 2016, 53).

The development requires a short and instant time. Thus, serious efforts are needed to strengthen and develop continuously in line with the Unity of Sciences paradigm, which is the basis for the development of science at UIN Walisongo Semarang.

\section{Axiological Dimension of Islamic Education Paradigm}

In Islam, the teacher is the successor to the role and function of the prophet, so he must imitate the characteristics of the prophet, namely siddîq, amânah, tablîgh, and fatânah. First, șiddîq, the teacher must always be right and speak or speak the truth. Science must always think and act correctly to teach the truth wherever it is. Strictly speaking, teachers are forbidden to convey something wrong because something wrong can harm and mislead students and others (Maragustam 2021, 3-6).

A șiddî teacher will quickly recognize and acknowledge the truth, or he is a sincere person. Because indeed, someone who can admit the truth is only a truthful person. Without sincerity, people will find it difficult to profess the truth. (Syukur and Junaedi 2017, 145)

Second, trust (amânah). Teachers are human figures that must always behave honestly and trustworthy. They are not allowed or forbidden to lie, both in thoughts, words, and deeds. Honesty is the fundamental capital for teachers in teaching and educating their students, so they become human beings with noble personalities. Honesty will give birth to order, benefit, and happiness in this world and hereafter. The human civilization built on the values of honesty and truth will give birth to prosperity and prosperity in human life. In Surah al-Anfâl verse 27, it is, "O you who believe, do not betray Allah and His Messenger, nor do you betray the mandates entrusted to you, while you know (the problem)." In other words, trust is a moral and ethical ability that will allow humans (teachers) to build the positive and eliminate the negative. With that ability, the teacher can fulfill his mission as a caliph and the earth's life source and livelihood manager (Syukur and Junaedi 2017, 146).

Third, tabligh. A teacher is a person who conveys and transfers wisdom in the form of truth values and knowledge to students. Teachers must be sincere and open in conveying and transferring all their knowledge 
and not trying to hide or keep it. This task is implemented by educating and teaching in schools or madrasas. In teaching, teachers use various methods and media to be exciting and fun for their students. To carry out their tabligh duties properly, a teacher must have the ability to explain in simple, straightforward language so that it is easy to understand. In such a way, their students will easily understand problems (Maragustam 2021, 2015; Syukur and Junaedi 2017, 146).

Fourth, fatânah. The figure of a teacher is an extraordinary human being, so it can only be carried out by people who have good intelligence. Intelligence can solve various problems faced properly, effectively, efficiently, accurately, and quickly. The intelligence that the teacher must possess is in the form of rational intelligence or brain intelligence (Intellectual Quotient/IQ), emotional intelligence (Emotional Quotient/EQ), and spiritual intelligence or intelligence of the heart (Spiritual Quotient/SQ). Teachers must have a good IQ intelligence to solve mathematical logic, philosophical reasoning, and symbolic problems. Strictly speaking, an educator should not have a low level of intelligence, such as idiots, debilities, and imbeciles. Other than that, an educator must have good emotional intelligence (EQ). Emotional intelligence includes selfcontrol, enthusiasm and persistence, and the ability to motivate oneself and others. So that teachers with qualified emotional intelligence will easily empathize with their students. Also will not get angry quickly because they can control themselves and easily adapt to their environment. So, according to Daniel Goleman, emotional intelligence will determine a person's success (Syukur and Junaedi 2017, 146).

In addition to these two bits of intelligence, an educator should have spiritual intelligence (SQ). Good spiritual intelligence makes an educator have a high awareness of God so that he will always obey His commands and stay away from everything He forbids. An educator with spiritual intelligence will always decorate his life by always remembering Allah (dhikr Allâh) (Syukur and Junaedi 2017, 147).

Professional knowledge such as education and teacher training is a very noble job. It has a goal to build and educate human children who will determine the nation's future. What a heavy burden that is placed on an educator. The strategic role of educators demands the work of professional educators and can develop a variety of hidden potentials in students. Such is the educators' role in making changes to civilization through students who will determine the future. On this basis, it triggered the issuance of the 
Law on Teachers and Lecturers to prosper and protect the lives of educators (Syukur and Junaedi 2017, 147).

Therefore educators can be positioned as a substitute for parents in schools. In traditional society, an educator is someone to imitate and cannot be ignored. He knows about everything that other people don't know. Educators at that time became the only source of information and a source of truth. The recruitment of educators prioritizes moral qualifications rather than academic qualifications. Because in the view of the Unity of Sciences paradigm, it is not only science that is put forward but also moral examples. It glorifies the teaching profession and provides access to authority so that less than optimal performance can be covered to empower students' potential (Anbiya and Asyafah 2020, 27).

However, the role of educators will not be able to replace the role of parents, even though educators act as educators, because most of the roles of educators in schools are only limited to developing cognitive abilities that are far more dominant. Therefore, the position of parents to improve affective and emotional skills can be significant. Based on the description of the strategic position of educators and parents, a synergy between the two is needed to maximize the abilities possessed by children. Often some parents come to school when their son has problems with the institution or school.

Something routine needs changes either from the behavior of the openness of the school or parents. Schools with educators as service providers must be ready to implement changes that allow the development of the student's abilities to the maximum. The case of educators remains current and grows with the changes that surround, changes in science, technology, and the civilization of the people. Internally related to qualifications, competence, welfare, the guarantee of comfort, and the like. Externally, the crisis of moral ethics of the nation's children and the challenges of global citizens are indicated by high competence, transparency, efficiency, great quality, and professionalism (Syukur and Junaedi 2017, 298).

In developing an understanding of Islam, lecturers and students, especially the Faculty of Tarbiyah and Teacher Training UIN Walisongo, are designed not to be rigid in understanding Islamic sciences. Instead, students will become educators who can integrate science and religion conceptually and integrate both within themselves as a single unit.

It has also been stated by Muslim philosophers such as al-Fârâbî. Indeed, all scientific activities of the profession and, more specifically, 
education, for example, in al-Fârâbî's view, are the acquisition of individual's values, knowledge, and practical skills. Within a certain period and a certain local culture. Education aims to lead the individual to perfection since man was created for this purpose. The purpose of human existence living in this world is to achieve happiness, the highest perfection (al-Talbi 1993, 3).

The perfect man (insân kâmil), in al-Fârâbî's thought, is the person who has acquired the theory of virtue-thus completing the intellectual knowledge and has acquired virtue-so that practical morals become perfect in moral behavior. Then, these coronations are theoretical and moral virtues that, with their effective power, anchor in the souls of individual members of a group when they assume the responsibility of political leadership, thus becoming role models for others. Al-Fârâbî also unites moral and aesthetic values: good is beautiful, and beauty is good; beautiful is that which is appreciated by the intelligentsia (al-Talbi 1993, 3).

UIN Walisongo has a goal to under the thinking of classical Muslim scientists who apply Unity of Sciences. Non-dichotomous paradigms such as Unity of Sciences. Alumni are expected to have the capacity, physical, intellectual, and spiritual potential that is qualified. It aims to create the graduates with the profile of noble character and good personality, broadminded, up to date, can carry out tasks with a dedication to education and Islam. These are based on an integrated scientific and Islamic approach, and are responsible for carrying out tasks based on scientific and ethical ethics professional. Therefore, adab has a close relationship with wisdom (hikmah), justice ('adl), reality, and truth (haq), especially for scholar or alumni who have formed the Unity of Sciences paradigm in themselves.

\section{From Paradigm to Curriculum}

The transformation of IAIN Walisongo to UIN Walisongo is sought to impact scientific development significantly. Moreover, the transformation also impacts the institutional realm, even the reconstruction of religious understanding. It is called scientific reconstruction because when it turns into a UIN, study programs that develop scientific knowledge, social humanities, and others must be integrated into study programs included in the Islamic scientific family, which existed first. Moreover, the establishment of UIN also answered the discourse raised for a long time regarding the integration of science and religion. Therefore, the change to 
become a UIN is marked by reconstructing its scientific paradigm (Salahuddin 2014, 127).

Islamic education based on the Unity of Sciences paradigm can be explained in three perspectives. First, viewed from a philosophical perspective in which there are ontological, axiological, and epistemological studies. Philosophical studies have formulated essential scientific buildings based on the Unity of Sciences. This study is based on the vision and mission of UIN Walisongo. Second, from an institutional perspective. From this perspective, the Unity of Sciences paradigm changes the existing faculties and study programs, especially the addition and repositioning of the 'general science' clumps. Third, viewed from the perspective of the curriculum level, which includes aspects of the curriculum structure of universities, faculties, and departments/study programs. The curriculum developed at UIN Walisongo is formulated not only for the distribution of courses but also descriptions of courses that support integration and the learning process. In some cases, the Lecture Program Unit (SAP) document based on Unity of Science has also been formulated following the developed scientific paradigm.

For the curriculum to be appropriately implemented in-class lectures, the syllabus needs to be elaborated or developed into a Lecture Program Unit (SAP). SAP will describe the teaching and learning process details in each meeting. SAP contains competency standards, basic competencies, competency indicators, lecture materials and descriptions, learning experiences, learning media/tools, assessment systems, and references. As with the integration of sciences listed in the syllabus, the forms of integration in SAP at the Faculty of Tarbiyah and Teacher Training are formulated and integrated with supporting courses, and research development to revitalize local wisdom. In compiling the SAP, the lecturer enters the verses of the Quran that follow the topics discussed. This verse has indicated the use of an Islamic perspective in science. Furthermore, in the field of research, for students when working on their final project to raise research in terms of local wisdom. The revitalization of local wisdom is useful for strengthening national identity and responding to various acute problems of this nation and state, such as tolerance, corruption, poverty, and social inequality. 


\section{Conclusion}

Islamic Education paradigm developed by UIN Walisongo Semarang unites spiritual values and science. This perfection, which he expects from education, combines knowledge and virtuous behavior; it is happiness and goodness at the same time. Theoretical and practical perfection can only be found in society, for it is a society that nurtures the individual and prepares him to be free. If he lives outside society, he can only learn to be a beast, and one of the goals of education is creating an ideal society where all cities work together to achieve happiness.

Alumni are expected to have the capacity, physical, intellectual, and spiritual potential that is qualified. Later, they can create a profile of graduates who have noble character and pleasing personalities, are broadminded, up to date, can carry out tasks with a dedication to education and Islam. In addition, it is based on an integrated scientific and Islamic approach, and also being responsible for carrying out tasks based on scientific and professional ethics. Therefore, adab has a close relationship with wisdom (hikmah), justice ('adl), reality, and truth (haq). Moreover, scientists or alumni who have formed the Unity of Sciences paradigm develop religious knowledge that follows the times, is not rigid, and is friendly to local wisdom.

\section{References}

Abdullah, M. Amin. 2017. "Islam as a Cultural Capital in Indonesia and the Malay World: A Convergence of Islamic Studies, Social Sciences and Humanities." Journal of Indonesian Islam 11(2): 307-28.

DOI: https://doi.org/10.15642/JIIS.2017.11.2.307-328.

Al-Attas, Syed Muhammad Naquib. 1979. Aims and Objectives of Islamic Education. Jedah: King Abdul Aziz University.

Al-Talbi, Ammar. 1993. "Al-Farabi." Paris, UNESCO: International Bureau of Education XXIII(1): 47-60.

DOI: https://doi.org/10.1017/UPO9781844654642.005.

Alhamuddin, Alhamuddin. 2016. "Kurikulum Pendidikan Tinggi Keagamaan Islam: Mutu dan Relevansi." Al-Murabbi 3(1): 1-15.

Anbiya, Bakti Fatwa, and Abas Asyafah. 2020. "Implementasi Pembelajaran Mata Kuliah Wajib Umum Pendidikan Kewarganegaraan Berbasis 
Unity of Science." Journal of Moral and Civic Education 4(1): 32-41.

DOI: https://doi.org/10.24036/8851412412020220.

Aziz, Azniwati Abdul, Mohamed Akhiruddin Ibrahim, Mohammad Hikmat Shaker, and Azlina Mohamed Nor. 2016. "Teaching Technique of Islamic Studies in Higher Learning Institutions for Non-Arabic Speakers: Experience of Faculty of Quranic and Sunnah Studies and Tamhidi Centre, Universiti Sains Islam Malaysia." Universal Journal of Educational Research 4(4): 755-60.

DOI: https://doi.org/10.13189/ujer.2016.040412.

Azizy, Qodri. 2001. Membangun IAIN Walisongo Kedepan. Semarang: Gunung Jati.

Blueprint Pengembangan Akademik IAIN/UIN Walisongo Untuk 25 Tahun (2013-2038) IsDB IAIN Walisongo. 2013. Semarang.

Daud, Wan Mohd Nor Wan. 1989. The Concept of Knowledge in Islam and Its Implications For Education in Developing Country. London and New York: Mansel.

Fanani, Muhyar. 2015. "The Unity of Science as UIN Walisongo Paradigm: A Philosophical Approach." In Proceeding of The 1 St Joint International Seminar ISLAM, SCIENCE, AND CIVILIZATION: Prospect and Challenge for Humanity, Semarang: UIN Walisongo.

Fathorrahman. 2020. "Demokratisasi Pendidikan Dalam Pendidikan Islam.” Ilmuna 2(1): 36-47.

al-Ghazali. 1998. Ihya' Ulumuddin Jilid 1. ed. Ismail Yakub. Jurong Town Singapore: PUSTAKA NASIONAL PTE LTD.

Hasibuan, Albar Adetary. 2016. "Ta'dib Sebagai Konsep Pendidikan: Telaah Atas Pemikiran Naquib Al-Attas.” At-Turas 3(1): 43-54.

DOI: https://doi.org/https://doi.org/10.33650/at-turas.v3i1.181.

Hidayat, Muslih. 2014. "Pendekatan Integratif-Interkonektif: Tinjauan Paradigmatik dan Implementatif Dalam Pembelajaran Pendidikan Agama Islam.” Ta'dib 19(02): 276-87.

DOI: https://doi.org/10.1179/1743280415Y.0000000004.

Hussien, Suhailah, Arifin Mamat, and Ssekamanye Siraje Abdallah. 2018. "The Perceptions, Practices and Challenges of the Integration of 
Knowledge amongst the Academics of International Islamic University Malaysia (IIUM).” Al-Shajarah (Special Issue: EDUCATION): 117-30.

Jama, Abdinasir Hersi, Dawood A Y Al-Hidabi, Suhailah Hussien, and Mohamed Ridhuan Abdullah. 2020. "Influence of Curriculum and Demographic Factors on Somali Students' Civic Outcomes.” IIUM Journal of Educational Studies 8(1 $\quad$ SE-): 53-72. https://journals.iium.edu.my/ijes/index.php/iejs/article/view/305.

Junaedi, Mahfud, and Mirza Mahbub Wijaya. 2019. Pengembangan Paradigma Keilmuan Perspektif Epistemologi Islam: Dari Perenialisme Hingga Islamisasi, Integrasi-Interkoneksi dan Unity of Science. Jakarta: Prenadamedia Group.

Latief, Mohamad. 2018. "The Sociology of Knowledge: A Preliminary Analysis on The Sociological Approach to The Development of Islamic Religious Sciences.” ULUL ALBAB: Jurnal Studi Islam 19(2): 272-289.

DOI: https://doi.org/10.18860/ua.v19i2.5597.

Maragustam, Maragustam. 2021. "Strategi Pembentukan Karakter Spiritualitas Keagamaan Dan Cinta Tanah Air Dalam Perspektif Filsafat Pendidikan Islam." DAYAH: Journal of Islamic Education 4(1): $1-22$.

DOI: https://doi.org/10.22373/jie.v4i1.7122.

Nasiruddin, Nasiruddin. 2013. "Integrasi Sains dan Agama Dalam Pendidikan Islam.” Literasi 4(2): 171-88.

DOI: http://dx.doi.org/10.21927/literasi.2013.4(2).171-188.

Nasr, Seyyed Hossein. 2001. Science and Civilization. Chicago: ABC International Group.

Partanto, Pius A., and M. Dahlan Al Barry. 2001. Kamus Ilmiah Populer. Surabaya: Arkola.

Razali, Wan Mohd Fazrul Azdi Bin Wan, and Jaffary Awang. 2014. "A Preliminary Discourse on the Islamic Scientific Study of Religion with Reference to the Muslim Scholarship in Religionswissenschaft." 'Ulūm Islāmiyyah Journal 13(Special Edition): 197-208.

DOI: https://doi.org/10.12816/0012637. 
Rifai, Nurlena, Fauzan Fauzan, Wahdi Sayuti, and Bahrissalim Bahrissalim. 2014. "Integrasi Keilmuan Dalam Pengembangan Kurikulum di UIN Se-Indonesia: Evaluasi Penerapan Integrasi Keilmuan UIN Dalam Kurikulum dan Proses Pembelajaran.” TARBIYA: Journal of Education in Muslim Society 1(1): 13-43.

DOI: https://doi.org/10.15408/tjems.v1i1.1108.

Rozi, Syafwan. 2012. "Agama Dan Postmodernisme: Menelusuri Metodologi dan Pendekatan Studi-Studi Agama." Ilmu Ushuluddin 1(3): 231-244.

DOI: https://doi.org/10.15408/ilmu-ushuluddin.v1i3.1011.

Sa 'adi, Sa 'adi. 2011. "A Survey on The Development of Islamic Higher Education in Indonesia: An Epistemological Review." IJIMS, Indonesian Journal of Islam and Muslim Societies 1(1): 151-69.

DOI: https://doi.org/10.18326/ijims.v1i1.151-169.

Salahuddin, Marwan. 2014. "Model Pengembangan Pendidikan Tinggi Islam Di Indonesia." 'Ulumuna 18(1): 121-38.

DOI: https://doi.org/10.20414/ujis.v18i1.155.

Saqeb, Ghulam Nabi. 2000. "Some Reflections on Islamization of Education Since 1977 Makkah Conference: Accomplishments , Failures and Tasks Ahead." Intellectual Discourse 8(1): 45-68.

Suharto, Toto. 2015. "The Paradigm of Theo-Anthropo-Cosmocentrism: Reposition of the Cluster of Non-Islamic Studies in Indonesian State Islamic Universities." Walisongo: Jurnal Penelitian Sosial Keagamaan 23 (November 2015): 251-82.

DOI: https://doi.org/10.1016/j.radonc.2004.06.008.

Syarifah, Umaiyatus and Siti Fahimah. 2020. "Zaghlûl Râghib Muhammad Al-Najjâr's Methods and Principles of Scientific Exegesis: A Review of Tafsîr al-Âyât al-Kawniyyah fî al-Qur'ân al-Karîm." ULUL ALBAB: Jurnal Studi Islam 21(2): 289-311.

DOI: https://doi.org/10.18860/ua.v21i2.10227.

Syukur, Fatah, and Mahfud Junaedi. 2017. Pengembangan Profesi Guru Berbasis Unity of Science. Semarang: Walisongo Press.

Tahir Abdurrahman Abubakar, Abdul Hakim Abdullah, Adamu Zakiyu Ubale, and Rahimah Embong. 2016. "Islamic Education and the 
Implication of Educational Dualism.” Social Sciences (Pakistan) 11(2): 156-63.

DOI: https://doi.org/10.3923/sscience.2016.156.163.

Wijaya, Mirza Mahbub. 2019. Filsafat Kesatuan Ilmu Pengetahuan: Unity of Sciences Sebagai Format Integrasi Keilmuan UIN Walisongo. Semarang: Fatawa Publishing.

Wijaya, Mirza Mahbub, Mahfud Junaedi, and Sholihan. 2021. "Scientific Development Based on Unity of Sciences (Wahdat Al-'Ulum) Paradigm.” International Journal Ihya' 'Ulum al-Din 23(1): 1-26.

DOI: https://doi.org/10.21580/ihya.23.1.6732.

Yaqin, Ainol. 2016. "Integrasi Ilmu Agama Dan Sains: Kajian Atas Pemikiran Al-Ghazālī." Islamuna 3(1): 55-71.

DOI: https://doi.org/10.19105/islamuna.v3i1.946. 